\title{
In vitro and in vivo antitumor activity of crude extracts obtained from Brazilian Chromobacterium sp isolates
}

\author{
C.B.A. Menezes ${ }^{1,2}$, B.P. Silva ${ }^{1,2}$, I.M.O. Sousa ${ }^{1}$, A.L.T.G. Ruiz ${ }^{1}$, H.M. Spindola ${ }^{1}$, E. Cabral ${ }^{3}$, \\ M.N. Eberlin ${ }^{3}$, S.V. Tinti, J.E. Carvalho ${ }^{1}$, M.A. Foglio ${ }^{1,2}$ and F. Fantinatti-Garboggini ${ }^{1,2}$ \\ ${ }^{1}$ Centro Pluridisciplinar de Pesquisas Químicas, Biológicas e Agrícolas, Universidade Estadual de Campinas, \\ Campinas, SP, Brasil \\ ${ }^{2}$ Interunidades em Biotecnologia, Universidade de São Paulo, São Paulo, SP, Brasil \\ ${ }^{3}$ Laboratório Thomson Mass Spectrometry, Instituto de Química, Universidade Estadual de Campinas, \\ Campinas, SP, Brasil
}

\begin{abstract}
Natural products produced by microorganisms have been an important source of new substances and lead compounds for the pharmaceutical industry. Chromobacterium violaceum is a Gram-negative $\beta$-proteobacterium, abundant in water and soil in tropical and subtropical regions and it produces violacein, a pigment that has shown great pharmaceutical potential. Crude extracts of five Brazilian isolates of Chromobacterium sp $(0.25,2.5,25$, and $250 \mu \mathrm{g} / \mathrm{mL})$ were evaluated in an in vitro antitumor activity assay with nine human tumor cells. Secondary metabolic profiles were analyzed by liquid chromatography and electrospray ionization mass spectrometry resulting in the identification of violacein in all extracts, whereas FK228 was detected only in EtCE 308 and EtCE 592 extracts. AcCE and EtCE 310 extracts showed selectivity for NCI/ADR-RES cells in the in vitro assay and were evaluated in vivo in the solid Ehrlich tumor model, resulting in 50.3 and $54.6 \%$ growth inhibition, respectively. The crude extracts of Chromobacterium sp isolates showed potential and selective antitumor activities for certain human tumor cells, making them a potential source of lead compounds. Furthermore, the results suggest that other compounds, in addition to violacein, deoxyviolacein and FK228, may be involved in the antitumor effect observed.
\end{abstract}

Key words: Chromobacterium sp; Antitumor activity; Secondary metabolites; Genetic diversity; Violacein

\section{Introduction}

Microorganisms have become an important source of natural products of great interest to pharmaceutical industries. Among current commercially available drugs, approximately $63 \%$ are directly or indirectly derived from natural products from microorganisms, plants and animals (1). Chromobacterium violaceum is a Gram-negative $\beta$-proteobacterium, facultative anaerobic, saprophyte, free-living soil- and water-associated microorganism, found in tropical and subtropical regions and it is abundant in black waters and on the banks of Rio Negro, in Amazonas, Brazil (2). The main characteristic of this bacterium is the production of violacein, a purple pigment, which exhibits activity against important tropical pathogens such as Mycobacterium tuberculosis, Trypanosoma cruzi, Leishmania sp, and Plasmodium and is reported to have bactericidal, cytotoxic, antiviral, antifungal, antioxidant, antitumor (3), antiulcerogenic, immunomodulatory, analgesic, antipyretic, and anti-diarrheal $(4,5)$ activities. Several studies have shown that violacein is also capable of inducing apoptosis in a variety of cancer cell lines, including leukemia lineages, suggesting a promising clinical application to cancer treatment. The therapeutic application of violacein to cancer chemoprevention has been the focus of recent investigations $(6,7)$. Violacein has been shown to cause apoptosis in HL60 leukemic cells but is ineffective in normal human lymphocytes and monocytes (8). In all of the cases observed until now, the toxicity to normal cells requires larger amounts of violacein compared to cancer cells. The $\mathrm{IC}_{50}$ for cancer cells is about $1-3 \mu \mathrm{M}$, as opposed to about $8-10 \mu \mathrm{M}$ for normal cells (3).

Moreover the antitumoral cyclic depsipeptide FK228 (romidepsin, formerly FR901228; NSC 630176) was extracted from the C. violaceum WB968 strain. FK228 is

Correspondence: C.B.A. Menezes, Centro Pluridisciplinar de Pesquisas Químicas, Biológicas e Agrícolas, UNICAMP, Caixa Postal 6171, 13083-970 Campinas, SP, Brasil. E-mail: clbeatriz@cpqba.unicamp.br or clbeatriz2003@gmail.com 
a selective histone deacetylase inhibitor that has demonstrated potent cytotoxic activity against the human tumor cell lines A549 (lung), MCF7 (breast), SW480 (colon), and PC-3 (prostate) and in vivo efficacy against both human tumor xenografts and murine tumors. This metabolite has shown a great therapeutic potential when compared to trichostatin, a specific inhibitor of histone acetylation, and is a selective agent against chronic leukemia of the lymphocytic cells in clinical assays. Romidepsin was approved by the US Food and Drug Administration in 2009 for use in patients with cutaneous T-cell lymphoma, under the trade name Istodax, and offers a promising new treatment for a disease with few existing therapies (9).

Thus, the aim of this study was to evaluate the antitumor activity of crude extracts of Chromobacterium $\mathrm{sp}$ isolates from Minas Gerais and Amazonas, Brazil, and to establish a relationship between their differences in secondary metabolite compositions. The crude extracts showed cytotoxic activities with different potency and selectivity toward human tumor cell lines presented in this study. The presence or absence of compounds FK228 and violacein could not explain differences in antiproliferative activity demonstrated by extracts suggesting that other components are responsible for the antiproliferative activity.

\section{Material and Methods}

\section{Bacterial strains}

Four isolates used in this study are preserved in the Brazilian Collection of Industrial and Environmental Microorganisms (CBMAI, CPQBA, UNICAMP, Campinas, $\mathrm{SP}$, Brazil). The isolates were recovered from water samples in Rio Preto da Eva (CBMAI 308 and 310) and Presidente Figueiredo (CBMAI 307) municipalities in Amazonas, Brazil, and one of them (CBMAI 592) was isolated from soil samples of Serra do Cipó National Park, in Minas Gerais, Brazil. C. violaceum-type strain (ATCC $12472^{\top}$, USA; CBMAI $534^{\top}$ ) was used as reference in experiments.

\section{Phylogenetic analysis of the 16S rRNA genes}

Genomic DNA of Chromobacterium sp isolates was used to amplify 16S rRNA gene with the bacterial primer set $27 f$ and $1401 \mathrm{r}(10)$. The sequencing was carried out using the set of primers $28 \mathrm{f}\left(5^{\prime}\right.$-GAG TTT GAT CCT GGC TCA G-3'), 782r (5'-ACC AGG GTA TCT AAT CCT GT3'), $765 f$ (5'-ATT AGA TAC CCT GGT AG-3') and 1100r (5'-AGG GTT GGG GTG GTT G-3') according to manufacturer instructions (Invitrogen, Brazil). Partial 16S rRNA sequences obtained from isolates were assembled in a contig using the phred/Phrap/CONSED program. The sequences were aligned using the CLUSTAL $X$ program and analyzed with the MEGA software v.4. Evolutionary distances were derived from sequence-pair dissimilarities calculated as implemented in MEGA, using Kimura's DNA substitution model. The phylogenetic reconstruction was done using the neighbor-joining algorithm with bootstrap values calculated from 1000 replicate runs (10).

\section{Crude extract preparation}

Extracts derived from the metabolism of Chromobacterium $\mathrm{sp}$ isolates were obtained after strain growth in nutrient broth (Oxoid) medium at $30^{\circ} \mathrm{C}$ for $48 \mathrm{~h}$ at $150 \mathrm{rpm}$. The bacterial suspension ( $40-60 \mathrm{~g}$ cells) was centrifuged at $14.000 \mathrm{~g}$ for $10 \mathrm{~min}$ at $4^{\circ} \mathrm{C}$ to recover cells. Crude extracts of bacterial cells were obtained by sequential extraction with chloroform, ethyl acetate and ethanol solvents. The first crude extract obtained after $3 \mathrm{~h}$ of extraction with $150 \mathrm{~mL}$ chloroform was designated as chloroform crude extract (CICE). The second crude extract obtained after $6 \mathrm{~h}$ of extraction of the residue of the CICE extract with $150 \mathrm{~mL}$ ethyl acetate was denominated ethyl acetate crude extract (AcCE). The last one was obtained with ethanol $(150 \mathrm{~mL})$ after $10 \mathrm{~h}$ of extraction from the resulting residue of the AcCE extract and was denominated ethanol crude extract (EtCE). The crude extracts (CICE, AcCE, and EtCE) were concentrated under vacuum at $40^{\circ} \mathrm{C}$ (Büchi Rotovapor R200 with Büchi heating steam bath B490, Switzerland), until complete evaporation. The extracts were dissolved in dimethylsulfoxide (DMSO) and assayed for in vitro antitumor activity against human tumor cells. In addition, AcCE 310 and EtCE 310 extracts were evaluated for in vivo antitumor activity against a murine cancer model solid Ehrlich tumor.

\section{HPLC analysis coupled with diode array detection (DAD)}

Crude extracts were analyzed for the presence of violacein and deoxyviolacein by analytical HPLC-DAD (control system SCL-10A VP, Shimadzu, Japan) using a $3 \mu \mathrm{m}$ Phenomenex Prodigy C18 column $(150 \mathrm{~mm} \times$ $4.6 \mathrm{~mm})$. Violacein and the crude extract from Chromobacterium sp were diluted with $10 \mathrm{~mL}$ of the mobile phase $\left(\mathrm{H}_{2} \mathrm{O}\right.$ :acetonitrile $\left.60: 40, v / v\right)$ and filtered with a $0.45-\mu \mathrm{m}$ filter (Millipore, USA). Separation was performed using isocratic mode $\mathrm{H}_{2} \mathrm{O}$ :acetonitrile $(60: 40$, $\mathrm{v} / \mathrm{v}$ ) at a flow rate of $1 \mathrm{~mL} / \mathrm{min}$, and injection of a $20-\mu \mathrm{L}$ volume. Absorbance was monitored at 230 and $575 \mathrm{~nm}$.

\section{Electrospray ionization mass spectrometry (ESI-MS)}

Crude extracts were analyzed by ESI-MS to detect the presence of the depsipeptide FK228. ESI-MS was recorded on a $\mathrm{Q}-\mathrm{TOF}$ mass spectrometer (Micromass, UK) using direct infusion of a $10 \mu \mathrm{L} / \mathrm{min}$ methanol/ $\mathrm{H}_{2} \mathrm{O}$ $(1: 1)$ plus $0.1 \%$ formic acid solution and ionization by electrospray in the positive ion mode with an ESI-QqTOF configuration with an $\mathrm{m} / \mathrm{z}$ resolution of ca. 6.000 and ca. 10-30 ppm accuracy (high resolution). Major operation conditions were as follows: capillary voltage of $3.5 \mathrm{kV}$, cone voltage of $35 \mathrm{~V}$, source temperature of $100^{\circ} \mathrm{C}$, 
desolvation temperature of $80^{\circ} \mathrm{C}$ and collision energy of $70 \mathrm{eV}$. Continuous mass spectra were obtained by scanning from 100 to $900 \mathrm{~m} / \mathrm{z}$. The MassLynx 4.1 software was used (Waters, USA)

\section{In vitro antitumor activity assay}

A panel of nine human cancer cell lines, i.e., MCF-7 (breast), NCl/ADR-RES (ovarian cancer with a phenotype of multiple-drug resistance), UACC-62 (melanoma), NClH460 (non-small cell lung), PC-3 (prostate), HT29 (colon), OVCAR-3 (ovarian), 786-0 (renal), U251 (central nervous system), and one normal VERO cell line (monkey kidney normal cells) were used for in vitro antitumor activity assay. Cancer cell lines were obtained from the National Cancer Institute $(\mathrm{NCl})$ at Frederick, USA and were grown in RPMI-1640 medium (Sigma ${ }^{\circledR}$, USA) supplemented with $5 \%$ fetal bovine serum (Gibco ${ }^{\circledR}$, USA) at $37^{\circ} \mathrm{C}$ with $5 \%$ $\mathrm{CO}_{2}$. Cells were pricked when the cell monolayer reached $80 \%$ confluence in order to reach the ideal density to be inoculated. The inoculation density for each cell line was optimized by determining cell growth curves in a previous study (11).

Cells on $96-$ well plates $(100 \mu \mathrm{L}$ cells/well) were treated with $0.25,2.5,25$, and $250 \mu \mathrm{g} / \mathrm{mL}$ extracts in DMSO/ RPMI at $37^{\circ} \mathrm{C}, 5 \% \mathrm{CO}_{2}$ in air for $48 \mathrm{~h}$. The final DMSO concentration $(0.2 \%)$ did not affect cell viability. Cells were then fixed with $50 \%$ TCA and cell proliferation was determined by spectrophotometric quantification $(540 \mathrm{~nm})$ of cellular protein content using the sulforhodamine B assay (12). With a concentration-response curve for each cell line, TGI (concentration that produces total growth inhibition or a cytostatic effect) was determined by non-linear regression analysis (Table 1) using the Origin 7.5 software (OriginLab Corporation, USA). In the present study, the TGI endpoint was used to compare crude extract potency and specificity. A graphic representation (Mean Graph) was constructed to show differential cytotoxicity toward human tumor cell lines. The midline of each portion represents the mean TGI endpoint, calculated across nine cell lines. This mean value is then subtracted from the value for each individual cell line and plotted. More sensitive cell lines were visualized as bars deflecting to the right, whereas more resistant cell lines had bars extending to the left of the mean (Figure S1) $(13,14)$.

\section{Antitumoral activity in a murine cancer model - solid Ehrlich tumor (paws)}

Adult male Swiss mice $(25-35 \mathrm{~g})$ obtained from CEMIB (UNICAMP) were maintained under controlled conditions of temperature $\left(25 \pm 2^{\circ} \mathrm{C}\right)$ on a 12-h light/dark cycle and $45-65 \%$ humidity with food and water ad libitum for at least 7 days before the experiments. Studies were carried out in accordance with current guidelines for the veterinary care of laboratory animals (15) and with the recommendations of the Bioethics Committee of the Biology Institute (CEEA, UNICAMP, 1076-1).

Doxorubicin, as well as AcCE 310 and EtCE 310 extracts, were diluted in vehicle containing $1 \%$ Tween $^{80}$ (Sigma-Aldrich) in saline $(0.9 \% \mathrm{NaCl}$ diluted in distilled water). The tumor, derived from a spontaneous murine mammary adenocarcinoma, was maintained in the ascitic form by sequential passages in Swiss mice by weekly ip transplantations of $5 \times 10^{5}$ tumor cells. The cells were then diluted in $0.9 \%$ phosphate-buffered saline for a final inoculation density of $2.5 \times 10^{6}$ cells $60 \mu^{-1}$.animal ${ }^{-1}$ $(16,17)$.

Experiments were designed according to Kleeb et al.

Table 1. Cytotoxic activity, reported as TGI values, of crude extracts of Chromobacterium sp isolates tested against human tumor cell lines.

\begin{tabular}{|c|c|c|c|c|c|c|c|c|c|c|c|}
\hline & U251 & $\begin{array}{l}\text { UACC- } \\
62\end{array}$ & MCF-7 & $\begin{array}{c}\mathrm{NCl} / \\
\text { ADR-RES }\end{array}$ & $786-0$ & $\begin{array}{l}\mathrm{NCl}- \\
\mathrm{H} 460\end{array}$ & PC-3 & OVCAR-3 & HT29 & VERO & $\begin{array}{l}\text { TGI } \\
\text { mean } \\
\text { value }\end{array}$ \\
\hline AcCE 307 & 1.11 & 0.77 & 5.57 & 0.73 & 1.79 & 4.24 & 3.71 & 2.56 & 2.91 & 1.62 & $2.50 \mathrm{P}$ \\
\hline EtCE 307 & 5.74 & 6.33 & 22.84 & 9.00 & 7.76 & 7.33 & 12.75 & 5.96 & 23.18 & 9.81 & $11.07 \mathrm{M}$ \\
\hline AcCE 308 & 2.87 & 1.07 & 50.90 & 9.22 & 0.98 & 113.57 & 2.69 & 0.83 & 83.51 & 5.62 & $27.12 \mathrm{~W}$ \\
\hline EtCE 308 & 101.47 & 58.68 & 327.30 & 58.98 & 46.75 & 219.58 & 89.35 & 66.96 & 234.80 & 58.65 & 126.25 I \\
\hline AcCE 310 & 9.30 & 7.32 & 133.24 & 4.46 & 5.17 & 183.45 & 8.85 & 10.58 & 55.41 & 5.43 & $42.32 \mathrm{~W}$ \\
\hline EtCE 310 & 12.66 & 7.53 & 118.79 & 5.03 & 5.46 & 150.85 & 9.65 & 13.18 & 9.44 & 6.99 & $33.95 \mathrm{~W}$ \\
\hline AcCE 534 & 2.79 & 2.62 & 71.41 & 5.39 & 2.28 & 76.27 & 5.09 & 1.47 & 46.03 & 5.94 & $21.92 \mathrm{~W}$ \\
\hline EtCE 534 & 40.25 & 45.92 & 165.06 & 54.63 & 41.08 & 238.25 & 41.53 & 40.27 & 55.80 & 105.64 & $82.84 \mid$ \\
\hline AcCE 592 & 6.04 & 2.97 & 75.75 & 3.94 & 3.53 & 31.01 & 10.57 & 3.63 & 6.07 & 2.96 & $14.64 \mathrm{M}$ \\
\hline EtCE 592 & 92.98 & 35.47 & 250.00 & 29.26 & 37.55 & 74.68 & 89.54 & 60.76 & 29.97 & 32.74 & 73.29 । \\
\hline
\end{tabular}

Data are reported as total growth inhibition (TGI) in $\mu \mathrm{g} / \mathrm{mL}$ (13). AcCE = ethyl acetate crude extract; EtCE = ethanol crude extract. U251 (central nervous system cancer), UACC-62 (melanoma), MCF-7 (breast cancer), NCI/ADR-RES (ovarian cancer expressing a multipledrug resistance phenotype), 786-0 (renal cancer), NCl-H460 (small cell lung carcinoma), PC-3 (prostate cancer), OVCAR-3 (ovarian cancer), HT29 (colon cancer), and VERO (monkey kidney normal cells). Mean TGI value = inactive (I; TGI >50 $\mu \mathrm{g} / \mathrm{mL}) ; \mathrm{weak}$ activity $(\mathrm{W} ; 15 \mu \mathrm{g} / \mathrm{mL}<\mathrm{TGI}<50 \mu \mathrm{g} / \mathrm{mL})$; moderate activity (M; $6.25 \mu \mathrm{g} / \mathrm{mL}<\mathrm{TGI}<15 \mu \mathrm{g} / \mathrm{mL}) ;$ potent activity $(\mathrm{P} ; \mathrm{TGI}<6.25 \mu \mathrm{g} / \mathrm{mL})(18)$. 
(16), with several modifications. The basal right hind paw volume of male Swiss mice ( $n=10 /$ group) was measured with a plethysmometer (Panlab, Spain) and the animals were then inoculated with $2.5 \times 10^{6}$ viable tumor cells in a volume of $60 \mu \mathrm{L}$ injected into the right hind footpad (16). Treatment started (ip) $24 \mathrm{~h}$ after cell inoculation and was applied every 3 days for 15 days. The doses used were $7.5 \mathrm{mg} / \mathrm{kg}$ for AtCE 310 and EtCE 310 and $5 \mathrm{mg} / \mathrm{kg}$ for doxorubicin (positive control). At the end of the experiment, animals were sacrificed and both hind paws were extracted and weighed. The weight differences, divided by body weight, were considered to be the relative tumor weight. Results are reported as \% inhibition \pm SD. All results were submitted to one-way analysis of variance (ANOVA), considering $P \leq 0.05$ to be a significant difference between the control and treated groups, followed by the Duncan test, using the StatSoft ${ }^{\circledR}$ software (USA). Graphs were designed using the Origin software (17).

\section{Results and Discussion}

The ethyl acetate and ethanol extracts of five Chromobacterium sp isolates (CBMAI 307, 308, 310, 592 , and $534^{\top}$ ) showed significant antiproliferative activities in a dose-dependent manner. None of the crude chloroform extracts showed significant activities and they were considered to be inactive. According to Fouche et al (18), four categories of extract activity were related to the mean TGI value: inactive (TGI $>50 \mu \mathrm{g} / \mathrm{mL}$ ), weak activity $(15 \mu \mathrm{g} / \mathrm{mL}<\mathrm{TGI}<50 \mu \mathrm{g} / \mathrm{mL})$, moderate activity $(6.25 \mu \mathrm{g} / \mathrm{mL}<\mathrm{TGI}<15 \mu \mathrm{g} / \mathrm{mL})$ and potent activity (TGI $<6.25 \mu \mathrm{g} / \mathrm{mL}$ ). AcCE presented more activity than EtCE. The most potent extract was AcCE 307 (mean TGI value $=2.50 \mu \mathrm{g} / \mathrm{mL}$ ) while EtCE 307 and AcCE 592 presented a moderate antiproliferative activity. On the other hand, AcCE 308, AcCE 310, EtCE 310, and AcCE 534 showed a weak antiproliferative activity while EtCE 308, EtCE 534 and EtCE 592 were inactive.

Of all five Chromobacterium sp isolates, CBMAI 307 yielded the most active extract, i.e., AcCE 307. This extract showed a selective antiproliferative effect against NCI/ADR-RES (ovarian expressing phenotype multiple drug resistance, $\mathrm{TGI}=0.73 \mu \mathrm{g} / \mathrm{mL}$ ), UACC-62 (melanoma, $\mathrm{TGI}=0.77 \mu \mathrm{g} / \mathrm{mL}$ ), U251 (glioma, TGI $=1.11 \mu \mathrm{g} / \mathrm{mL}$ ), 786-0 (renal, TGI $=1.79 \mu \mathrm{g} / \mathrm{mL}$ ), and VERO (normal renal cell line, $\mathrm{TGI}=1.62 \mu \mathrm{g} / \mathrm{mL}$; Table 1 , Figure S1). The difference in selectivity is reported in the mean graph of TGI values (Figure S1). The mean graph was developed by the $\mathrm{NCl}$ in order to emphasize the different effects of test samples on various human tumor cell lines, and was generated from a set of TGI values. Positive values project to the right of the vertical line and represent cellular sensitivities to the test extract that exceed the mean. Negative values project to the left and represent cell line sensitivities to the test extracts that are less than the average value $(13,14)$

HPLC-UV analyses of crude extracts obtained from Chromobacterium sp isolates were undertaken to establish a relationship of cytotoxic activity with the presence of violacein, a pigment with reported antitumor activity (3-8). No other compounds sensitive to UV detection in addition to violacein and deoxyviolacein were detected at the wavelengths measured (230 and $575 \mathrm{~nm}$ ). HPLC-UV analysis of the AcCE 307 extract demonstrated a 17:1 violacein/deoxyviolacein ratio (Figure S2).

Another important compound identified in C. violaceum is FK228, which has been reported to show high cytotoxicity for human tumor cell lines A549 (lung cancer), MCF-7 (breast cancer), SW 480 (colon cancer), PC-3 (prostate cancer), and murine leukemia (3) in in vitro evaluation. Since FK228 does not have a characteristic UV spectrum and therefore is more difficult to detect by UV, ESI-MS analysis was performed to detect the presence of this compound in the extracts evaluated. The presence of compound FK228 ions $[\mathrm{M}+\mathrm{H}]^{+}$at $\mathrm{m} / \mathrm{z}$ $541.2,[\mathrm{M}+\mathrm{Na}]^{+}$at $\mathrm{m} / \mathrm{z} 563.2$, or $[\mathrm{M}+\mathrm{K}]^{+}$at $\mathrm{m} / \mathrm{z} 579.2$ was monitored. Moreover, ESI-MS analysis confirmed the HPLC-UV analysis by the detection of violacein ion $[\mathrm{M}+\mathrm{H}]^{+}$at $\mathrm{m} / \mathrm{z} 344.12$ and deoxyviolacein $[\mathrm{M}+\mathrm{H}]^{+}$at $\mathrm{m} / \mathrm{z}$ 328.11. In contrast, ESI-MS analysis of AcCE 307 did not detect FK228 (data not shown).

On the other hand, EtCE 307 had a moderate antiproliferative activity (mean TGI value $=11.07 \mu \mathrm{g} / \mathrm{mL}$ ) with a very similar effect on U251 $(\mathrm{TGI}=5.74 \mu \mathrm{g} / \mathrm{mL})$, OVCAR-3 (ovarian, TGI $=5.96 \mu \mathrm{g} / \mathrm{mL}$ ), UACC-62 (TGI = $6.33 \mu \mathrm{g} / \mathrm{mL}$ ), NCl-H460 (lung, $\mathrm{TGI}=7.33 \mu \mathrm{g} / \mathrm{mL}$ ), 786-0 $(\mathrm{TGI}=7.76 \mu \mathrm{g} / \mathrm{mL}), \mathrm{NCl} /$ ADR-RES $(\mathrm{TGI}=9.00 \mu \mathrm{g} / \mathrm{mL})$, and VERO (normal renal cell line, TGI $=9.81 \mu \mathrm{g} / \mathrm{mL}$ ) cell lines (Table 1, Figure S1). HPLC-UV analysis of EtCE 307 at 575 and $230 \mathrm{~nm}$ revealed only the presence of violacein with no detection of deoxyviolacein. Moreover ESI-MS analysis of this extract detected the presence of FK228.

Another extract that presented a moderate antiproliferative activity was AcCE 592 (mean TGI value = $14.64 \mu \mathrm{g} / \mathrm{mL}$ ) with a selective effect on UACC-62 (TGI = $2.97 \mu \mathrm{g} / \mathrm{mL}), 786-0 \quad(\mathrm{TGI}=3.53 \mu \mathrm{g} / \mathrm{mL})$, OVCAR-3 (ovarian, $\mathrm{TGI}=3.63 \mu \mathrm{g} / \mathrm{mL}$ ), NCl/ADR-RES $(\mathrm{TGI}=$ $3.94 \mu \mathrm{g} / \mathrm{mL}$ ), and VERO (normal renal cell line, TGI = $2.96 \mu \mathrm{g} / \mathrm{mL}$ ) cell lines (Table 1). HPLC-UV analysis of AcCE 592 demonstrated a 1:1 violacein/deoxyviolacein ratio and the absence of FK228 by ESI-MS analysis (Figure S2).

Among the extracts with weak antiproliferative activity, AcCE 534, AcCE 308, AcCE 310, and EtCE 310 presented mean TGI values of 21.92 to $42.32 \mu \mathrm{g} / \mathrm{mL}$. AcCE 534 was selective for OVCAR-3 (TGI $=1.47 \mu \mathrm{g} /$ $\mathrm{mL}), 786-0(\mathrm{TGI}=2.28 \mu \mathrm{g} / \mathrm{mL})$, UACC-62 $(\mathrm{TGI}=$ $2.62 \mu \mathrm{g} / \mathrm{mL})$, and $\mathrm{U} 251(\mathrm{TGI}=2.79 \mu \mathrm{g} / \mathrm{mL})$ cell lines, while AcCE 308 presented selectivity for OVCAR-3 $(\mathrm{TGI}=0.83 \mu \mathrm{g} / \mathrm{mL}), 786-0(\mathrm{TGI}=0.98 \mu \mathrm{g} / \mathrm{mL})$, 
UACC-62 $(\mathrm{TGI}=1.07 \mu \mathrm{g} / \mathrm{mL}), \mathrm{U} 251(\mathrm{TGI}=2.87 \mu \mathrm{g} /$ $\mathrm{mL}$ ), and PC-3 (prostate, $\mathrm{TGI}=2.69 \mu \mathrm{g} / \mathrm{mL}$ ). HPLC-UV analysis of both AcCE 534 and AcCE 308 demonstrated a similar violacein/deoxyviolacein proportion (13:1 and 15:1, respectively), besides the absence of FK228 by ESI-MS analysis (Figure S2).

On the other hand, both AcCE and EtCE 310 presented a similar selectivity for NCI/ADR-RES ( $\mathrm{TGI}=$ 4.46 and $5.03 \mu \mathrm{g} / \mathrm{mL}$, respectively), 786-0 ( $\mathrm{TGI}=5.17$ and $5.46 \mu \mathrm{g} / \mathrm{mL}$, respectively) and VERO (TGI $=5.43$ and $6.99 \mu \mathrm{g} / \mathrm{mL}$, respectively) cell lines (Table 1, Figure S1). Also, both AcCE and EtCE 310 demonstrated a similar violacein/deoxyviolacein proportion (20:1 and 34:1, respectively) by HPLC-UV analysis, besides the absence of FK228 by ESI-MS analysis (Figure S2).

These results suggest that the ratio of violacein/ deoxyviolacein alone does not explain the differences observed in antiproliferative activity, as exemplified by the potent antiproliferative activity presented by AcCE 307 while AcCE 534 presented just a weak antiproliferative effect. Both extracts presented a similar violacein/deoxyviolacein ratio (17:1 and 13:1, respectively; Figure S2).

Similarly, the presence or absence of compound FK228 could not explain differences in antiproliferative activity as demonstrated by EtCE 307, EtCE 308, and EtCE 592. FK228 was identified in all of these extracts, although EtCE 307 presented a potent antiproliferative effect while EtCE 308 and EtCE 592 were inactive, suggesting that other components are responsible for the antiproliferative activity of EtCE 307.

Jensen et al. (19) reported associations between secondary metabolite production and phylogenetically distinct but closely related marine actinomycete species belonging to the genus Salinispora. The pattern emerged in a study that included global collection sites and this indicates that secondary metabolite production can be a species-specific phenotypic trait associated with broadly distributed bacterial populations. The cytotoxic activities with different potency and selectivity towards human tumor cell lines presented in this study may be explained by several secondary metabolites produced by the isolates evaluated. In addition, this marked metabolic diversity may be related to the great genetic diversity presented by Brazilian Chromobacterium sp isolates. 16S rRNA gene sequencing-based analysis of isolates showed that CBMAI 307 and CBMAI 308 were closely related to the strain types $C$. violaceum and $C$. pseudoviolaceum, while the CBMAI 592 strain clustered with $C$. piscinae and the CBMAI 310 strain may belong to a new species of the genus, not yet described (data not shown).

Regarding the possibility of CBMAI 310 belonging to a new species and the cytotoxicity observed for AcCE 310 and EtCE 310 extracts, both extracts had been evaluated in an in vivo experimental model in order to confirm their antitumor activity in a preliminary study. AcCE 310 and EtCE 310 extracts $(7.5 \mathrm{mg} / \mathrm{kg}$, ip) resulted in a reduction

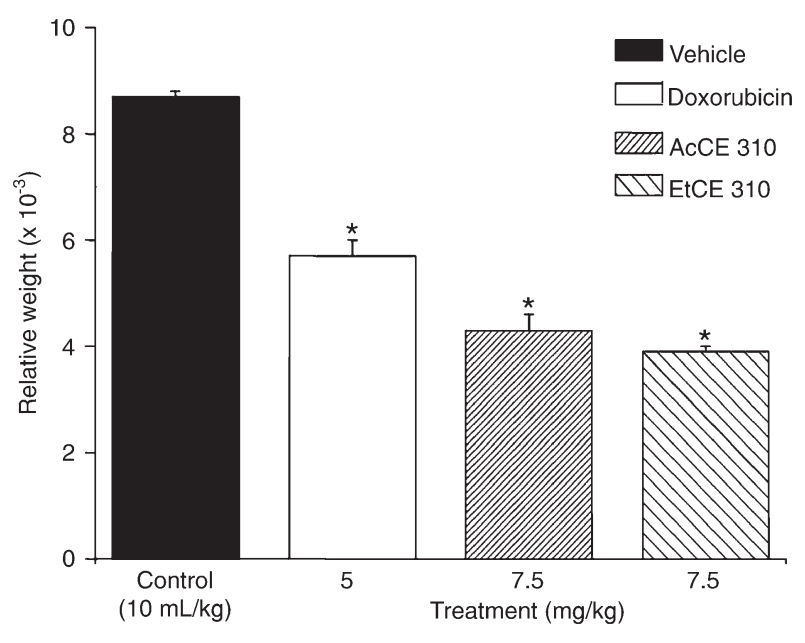

Figure 1. Effect of AcCE 310 and EtCE 310 on relative solid tumor weight (difference of weights of healthy leg and leg with tumor divided by body weight). Graph demonstrating relative tumor weight after a 15-day experimental period. Treatments: control group (vehicle, $10 \mathrm{~mL} / \mathrm{kg}$ ), doxorubicin $(5 \mathrm{mg} / \mathrm{kg}$ ), AcCE 310 and EtCE 310 extracts $(7.5 \mathrm{mg} / \mathrm{kg})$, given every 3 days, ip, for 15 days. Data are reported as means \pm SEM for 8 to 10 animals per experimental group. AcCE = acetate crude extract; EtCE $=$ ethanol crude extract. ${ }^{*} \mathrm{P} \leq 0.001$ compared to control (ANOVA followed by the Duncan test).

of tumor relative weight of 50.3 and $54.6 \%$ ( $P \leq 0.001)$, respectively, compared to the control group (Figure 1). These results indicated that both extracts were effective in reducing tumor cell growth, confirming the antitumoral activity of CBMAI 310 extracts, previously observed in in vitro cytotoxicity assays. The systemic antitumor activity was evaluated using the Ehrlich solid carcinoma in mice, a rapidly growing tumor with very aggressive behavior, able to grow in almost all mouse strains, which suggests that the recognition of and the immune responses to this tumor are independent of the major histocompatibility complex, being controlled more by innate immunity (inflammatory response) than by a T-cell response (20).

The in vitro antiproliferative activity of extracts obtained from Chromobacterium $\mathrm{sp}$ isolates presented in this study suggests that compounds other than violacein, deoxyviolacein and FK228 should also be involved in distinct mechanisms of action. Furthermore, the AcCE 310 and EtCE 310 extracts obtained from a new candidate within the genus Chromobacterium, which showed significant reduction in a murine cancer model can be a source for the discovery of new metabolites for anticancer drug development.

\section{Supplemental material}

Figure S1

Figure S2 


\section{Acknowledgments}

We would like to acknowledge the contribution of Dr. Spartaco Astolfi Filho, Universidade Federal do

\section{References}

1. Newman DJ, Cragg GM. Microbial antitumor drugs: natural products of microbial origin as anticancer agents. Curr Opin Investig Drugs 2009; 10: 1280-1296.

2. Hungria M, Astolfi-Filho S, Chueire LM, Nicolas MF, Santos $E B$, Bulbol MR, et al. Genetic characterization of Chromobacterium isolates from black water environments in the Brazilian Amazon. Lett Appl Microbiol 2005; 41: 1723, doi: 10.1111/j.1472-765X.2005.01724.x.

3. Duran N, Menck CF. Chromobacterium violaceum: a review of pharmacological and industiral perspectives. Crit Rev Microbiol 2001; 27: 201-222, doi: 10.1080/20014091096747.

4. Antonisamy P, Ignacimuthu S. Immunomodulatory, analgesic and antipyretic effects of violacein isolated from Chromobacterium violaceum. Phytomedicine 2010; 17: 300-304, doi: 10.1016/j.phymed.2009.05.018.

5. Antonisamy $P$, Kannan $P$, Ignacimuthu $S$. Anti-diarrhoeal and ulcer-protective effects of violacein isolated from Chromobacterium violaceum in Wistar rats. Fundam Clin Pharmacol 2009; 23: 483-490, doi: 10.1111/j.14728206.2009.00701.x.

6. Melo PS, Justo GZ, De Azevedo MB, Duran N, Haun M. Violacein and its beta-cyclodextrin complexes induce apoptosis and differentiation in HL60 cells. Toxicology 2003; 186: 217-225, doi: 10.1016/S0300-483X(02)00751-5.

7. Saraiva VS, Marshall JC, Cools-Lartigue J, Burnier MN, Jr. Cytotoxic effects of violacein in human uveal melanoma cell lines. Melanoma Res 2004; 14: 421-424, doi: 10.1097/ 00008390-200410000-00014.

8. Ferreira $\mathrm{CV}$, Bos $\mathrm{CL}$, Versteeg $\mathrm{HH}$, Justo $\mathrm{GZ}$, Duran $\mathrm{N}$, Peppelenbosch MP. Molecular mechanism of violaceinmediated human leukemia cell death. Blood 2004; 104: 1459-1464, doi: 10.1182/blood-2004-02-0594.

9. VanderMolen KM, McCulloch W, Pearce CJ, Oberlies NH. Romidepsin (Istodax, NSC 630176, FR901228, FK228, depsipeptide): a natural product recently approved for cutaneous T-cell lymphoma. J Antibiot 2011; 64: 525-531, doi: 10.1038/ja.2011.35.

10. Menezes CBA. Análise da diversidade genética por MLSA e avaliação da atividade antitumoral de linhagens de Chromobacterium sp. [Master's thesis]: Instituto de Ciências Biomédicas, Universidade de São Paulo; 2009. http://www.teses.usp.br/teses/disponiveis/87/87131/tde17042009-115257/pt-br.php
Amazonas, Brazil, by acquiring Chromobacterium sp strains for the Industrial and Environmental Microorganisms Brazilian Collection. Research supported by FAPESP and CNPq.
11. Kohn LK, Pizão PE, Foglio MA, Antônio MA, Amaral MCE, Bittric $\mathrm{V}$, et al. Antiproliferative activity of crude extract and fractions obtained from Aspidosperma tomentosum Mart. Rev Bras PI Med 2006; 8: 110-115.

12. Monks A, Scudiero D, Skehan P, Shoemaker R, Paull K, Vistica D, et al. Feasibility of a high-flux anticancer drug screen using a diverse panel of cultured human tumor cell lines. J Natl Cancer Inst 1991; 83: 757-766, doi: 10.1093/ jnci/83.11.757.

13. Shoemaker $\mathrm{RH}$. The NCl60 human tumour cell line anticancer drug screen. Nat Rev Cancer 2006; 6: 813-823, doi: 10.1038/nrc1951.

14. Holbeck SL. Update on $\mathrm{NCl}$ in vitro drug screen utilities. Eur J Cancer 2004; 40: 785-793, doi: 10.1016/ j.ejca.2003.11.022.

15. Voipio HM, Baneux P, Gomez de Segura I, Hau J, Wolfensohn S. Guidelines for the veterinary care of laboratory animals: report of the FELASA/ECLAM/ESLAV Joint Working Group on Veterinary Care. Lab Anim 2008; 42: 1-11, doi: 10.1258/la.2007.007027.

16. Kleeb SR, Rizzo dos S, Dagli ML, Frussa-Filho R. Haloperidol increases spreading and nitric oxide production in macrophages from tumor-bearing mice: a possible mechanism for its antitumoral effect. Int J Immunopharmacol 1999; 21: 575580, doi: 10.1016/S0192-0561(99)00036-3.

17. Vendramini-Costa DB, Castro IBD, Ruiz ALTG, Marquissolo C, Pilli RA, Carvalho JE. Effect of goniothalamin on the development of Ehrlich solid tumor in mice. Bioorg Med Chem 2010; 18: 6742-6747, doi: 10.1016/j.bmc.2010.07.053.

18. Fouche G, Cragg GM, Pillay P, Kolesnikova N, Maharaj VJ, Senabe J. In vitro anticancer screening of South African plants. J Ethnopharmacol 2008; 119: 455-461, doi: 10.1016/ j.jep.2008.07.005.

19. Jensen PR, Williams PG, Oh DC, Zeigler L, Fenical W. Species-specific secondary metabolite production in marine actinomycetes of the genus Salinispora. Appl Environ Microbiol 2007; 73: 1146-1152, doi: 10.1128/AEM.01891-06.

20. Segura JA, Barbero LG, Marquez J. Ehrlich ascites tumour unbalances splenic cell populations and reduces responsiveness of T cells to Staphylococcus aureus enterotoxin B stimulation. Immunol Lett 2000; 74: 111-115, doi: 10.1016/ S0165-2478(00)00208-X. 